\title{
An Examination of the Relationship Between Peer Bullying and Academic Motivation in Secondary School Students
}

\author{
Aynur Bütün Ayhan', Utku Beyazit ${ }^{2, *}$, Yeşim Yurdakul ${ }^{3}$ \\ ${ }^{1}$ Prof. Dr., Ankara University, Health Sciences Faculty, Child Development Department, Ankara, Turkey, \\ ${ }^{2}$ Assist. Prof. Dr., Akdeniz University, Kumluca Health Sciences Faculty, Child Development Department, \\ Antalya, Turkey \\ ${ }^{3}$ ME.D., Ministry of National Education, İsmail İltemir Primary School, Antalya, Turkey, yesim.yurdakul
}

*Corresponding author

\begin{abstract}
.
Peer bullying among children is a common problem in most cultures. As this phenomenon occurs mostly in school settings, it's negative effects on the academic motivation of the students is a subject matter. Despite of this subject's being a scientific concern worldwide, bullying at secondary schools and its links with the academic motivation remained unnoticed and unstudied in Turkey where academic mastery at school is mostly elaborated as an educational matter. From this perspective in this study, it is aimed to examine the relationship between peer bullying and academic motivation in secondary school students. A number of 262 students attending to three seperate secondary schools in the city center of Antalya, Turkey are included in the study. As the data gathering instruments, a Socio-Demographic Information Form, Peer Bullying Scale and Academic Motivation Scale were administered. As a result it was found that adolescents' level of the extrinsic motivation increase and intrinsic motivation decrease as their level of bullying acts increase. On the other hand, the adolescents' level of the intrinsic motivation is found to decrease as their level of victimization in bullying acts increase. The findings were discussed in terms of the relevant literature and suggestions were made in regards with the avoidance of peer bullying at schools.
\end{abstract}

Keywords: peer, peer bullying, academic motivation 


\section{SOCIAL SCIENCES IN THE 21ST CENTURY}

\section{Introduction}

Peer bullying among children appears to be a common problem in most cultures. Olweus (2013) defined bullying as a victimization which is characterized by unwanted aggressive behaviors or acts involving an interpersonal relationship that invloves an imbalance of power. It involves a high likelihood of resulting in both pyhsical and emotional harm of the children who cannot easily defend themselves (Smith, 2011; Schott, 2014). Bullying is viewed as a multidimensional act which can occur in verbal, physical and relational forms (Gladden et al., 2014). The most common forms of bullying are name calling, verbal insults, rumors, gestures or threating notes, making inappropriate sexual comments, social exclusion; direct physical aggression such as hitting, punching, kicking, property damage and theft (Bradshaw et al., 2015; UNESCO, 2017). Besides these common forms, bullying may ocur in cyberspace through the use of email, texts, cell phones, Internet chatrooms, websites (Deschamps \& McNutt, 2016). This new dimension of bullying is called cyberbullying, electronic bullying or online bullying (Langos \& Sarre, 2015).

Bullying appears to be a widespread problem among adolescents. In a study, which invloved students in 6th and 10th garde in 25 countries, Nansel et al. (2004) found that the prevalence of bullying varied from $9 \%$ to $54 \%$ across all countries. Rosen (2017) pointed out that the prevalence of bullying vary by grade level; that is, it reaches to a peak level around 11 years of age and then gradually decreases. The prevalence of bullying is pointed out to be the highest among middle schools as it occurs on a weekly or daily basis (Dupper, 2013). The transition from childhood to adolescence is a developmental challenge and difficulties in this passage may result in emotional and academic problems. The onset of puberty mostly brings biological and psychosocial challenges which may cause a heightened level of distress and cause the middle school students be more vulnerable to psychosocial stress such peer victimization (Espelage \& Holt, 2001). As much as age and grade level, gender is shown to be prominent correlate of peer bullying in adolescence. In general, boys are more involved in bullying as bullies whereas females are more likely to be the victims (Vaillancourt et al., 2008). Disadvantaged adolesecents such the adolescents coming from low socioeconomic status, cultural or ethnic differences and the ones who have indicators such as displacement or migration are at highest risk of being bullied (Mitchell 2018). On the other hand, adolescents who lack social skills; use aggression to gain power, social status and popularity among peers (Peeters et al., 2010; Graham, 2016); raised by abusive and neglectful parents who use aggression as a means of discipline (Smith, 2011) are at greater risk of bullying.

As the most common form of aggression among adolescents, bullying has physical, emotional and social consequences on the students' well-being and the school climate in general (Bradshaw \& Johnson, 2011). In a number of studies, it is shown that victims of bullying may experience low self-esteem (Blood et al., 2011), anxiety and depression (Hunter et al., 2007; Stapinski et al., 2014), physical complaints (Kaltiala-Heino et al., 2000), suicide (Klomek et al., 2008; Hinduja \& Patchin, 2010), and social isolation (Seeds et al., 2010). As a phenomenon mostly occuring in school settings, one of the most prominent and negative effect of bullying is on the academic success of the adolescents. In a number of studies it was shown that negative encounters with peers has negatively effects on academic tasks as it causes stress, inhibits learning and academic performance (Schwartz et al., 2005; Graham, Bellmore, \& Mize, 2006). A student who is exposed to bullying behaviors by peers at school, expriences anxiety of being ridiculed, excluded or being victim of physical violence, has 


\section{SOCIAL SCIENCES IN THE 21ST CENTURY}

difficulty in concentrating, stop attending classes or even may loose motivation in academic tasks (Espelage et al., 2013).

Adolescence is a period in which self-worth is predominantly determined by peer socialization and self-worth (Kulaksizoğlu, 2005). In the school setting, experiences of success and mastery is crucial for a student to gain self-esteem and a sense of satisfaction which would create a positive affect by facilitating the learning. According to Slee and Skrzypiec (2016) well-being at school is enhanced when the students are satisfied with their experiences with peers at school; that is, the positive relationships with peers impact academic achievement and motivation. Mastery at school involves an association between learning and well-being at school as students' sense of safety, belonging to school, and a feeling of connectedness influence academic motivation which is one of the most crucial preconditions of learning (Konishi et al., 2010). A student experiencing difficulties due to victimization and negative relationships with peers at school, may not be not ready for learning due to a loss of academic motivation (Bacanlı and Şahinkaya, 2011).

According to Lepper et al. (2005) academic motivation have extrinsic and intrinsic components. Intrinsic motivation refer to an individual interest and curiosity to learn, whereas extrinsic motivation refer to the extent to which behaviors are controlled by external factors and are mainly based on motives such as pleasing the parents or the teacher, receiving good grades and appraisal. It is thought that an impairment in intrinsic motivation may cause psychological diffculties in the adolescents' individual satisfaction and pleasure in learning. Hence, particularly an intrinsic motivation in academic tasks may not be possible in a school climate where the students expriences emotional stress due to victimization. The literature discussed above reveals that bullying at school may significantly influence the adolescents behaviors and learning. The phenomenon has been an object of many researches lately as bullying at school became widespread. Despite of the subject's being a scientific concern worldwide, bullying at secondary schools and its links with the academic motivation remained unnoticed and unstudied in Turkey where academic mastery at school is mostly elaborated as an educational matter. Taking this as the starting point, in this study, it was aimed to examine the relationship between peer bullying and academic motivation in secondary school students.

\section{Method}

\subsection{Participants}

The participants of the study consisted of 262 adolescents, attending to three seperate secondary schools in the city center of Antalya, Turkey in 2018-2019 spring semester. In terms of selecting the schools that the study is planned to be implemented, the Ministry of National Education was consulted and information is obtained about the socio-demographic profiles and the number of students enrolled in secondary schools. The three schools were

Chosen by considering how they represented the socio-demographic characteristics of the overall population. 


\section{SOCIAL SCIENCES IN THE 21ST CENTURY}

A total of $58.8 \%(n=154)$ of the adolescents were female and $41.2 \%(n=108)$ of them were male. The age mean of the adolescents were $12.42 \pm 1.19$ and their ages varied between 11 and 15. In terms of their grades, $20.6 \%(n=54)$ of the adolescents were attending fifth grade, $28.6 \%(n=75)$ of them were attending sixth grade, $27.1 \%(n=71)$ of them were attending seventh grade and $23.7 \%(n=62)$ of them were attending eight grade.

\subsection{Instruments:}

In the study, an Individual Information Form is administered for the purpose of gathering socio-demographic information from the adolescents. In addition, the adolescents were administered Academic Motivation Scale for the purpose of assessing their level of academic motivation and Peer Bullying Scale Adolescent Form was administered for the purpose of assessing the level of adolescents' being exposed to peer bullying and the level of exposing bullying to their peers.

Individual Information Form. The Individual Information Form, which was prepared by the researchers, included questions regarding the adolescents' school, gender, age and grade.

Academic Motivation Scale (AMS). The scale was developed by Leeper et al. (2005) for the purpose of assessing extrinsic and intrinsic motivation in terms of the students' academic motivation. The scale is consisted of 33 likert type items in two subcales as extrinsic and intrinsic motivation. The Extrinsic Motivation Subscale is consisted of 17 items and the Intrinsic Motivation Subscale is consted of 16 items. The scoring of the items range from not like me at all (1) to exactly like me (5). The subscale scores are computed by summation of all items in the relevant subscale and each subscale scores are computed seperately. The scores of the Extrinsic Motivation Subscale vary between 16 and 80 and the scores of the Intrinsic Motivation Subscale vary between 17 and 85. Higher scores indicate higher levels of extrinsic and intrinsic academic motivation.

In the reliability analysis of the original scale, the correlation coefficient of the Extrinsic Motivation Subscale is found to be .87 and .90 for the Intrinsic Motivation Subscale. The scale was adopted into Turkish by Bacanlı and Şahinkaya (2011). In the analysis, the correlation coefficient of the Extrinsic Motivation Subscale is found to be .70 and .77 for the Intrinsic Motivation Subscale. For this study, the Cronbcah alpha coefficient is computed as .75 for Extrinsic and .91 for Intrinsic Motivation subscale.

Peer Bullying Scale Adolescent Form (PBSA). The scale was developed by Ayas and Pişkin (2015) in order to assess peer bullying behaviors of the adolescents and the victims of bullying behaviors by their peers. The scale consisted of two subscales as The Bully and the Victim subscale. Both subscales consisted 53 likert type items and the scoring of the items range from almost everyday (4) to never (0). The scores of the both subscales vary between 0 and 212. The higher scores in The Bully subscale show higher levels of peer bullying behaviors whereas the higher scores in The Victim subscale show higher levels of being victim of bullying behaviors by peers.

In the reliability study of the scale, the Cronbach alpha coefficient of the The Bully Subscale was found to be .92 and .93 for the Victim Subscale (Ayas \& Pişkin 2015). In this study, the Cronbach alpha coefficient was found to be .95 for and The Victim and .96 for The Bully subscale. 


\section{SOCIAL SCIENCES IN THE 21ST CENTURY}

\subsection{Data Collection and Data Analysis}

The data collection procedure of the study was carried out in accordance with the 2008 Helsinki Decleration. Initially, the necessary permissions were provided from the authors of the instruments implemented, from the Ministery of Education and the school administrations. In each classroom the teachers and the adolescents were informed about the content of the study; and were explained that participation in the study is on voluntary basis and their answers would be kept confidential. The forms were administered to a number of 274 adolescents. However, 18 forms were excluded due to the high number of omitted items. Consequently, a number of 262 forms were included in the statistical analysis. SPSS 22 software was used for the analysis of the collected data. Initially, a normality test was performed regarding whether parametric test conditions have been established or not (Tabachnick \& Fidel, 2013). The results of the Kolmogorof-Smirnov test showed that parametric test conditions were not established ( $\mathrm{p}>.05)$. Thus, Spearman's correlation coefficient was taken into account in the correlation analysis.

\section{Results}

The arithmetic means and the standard deviations regarding Academic Motivation Scale and Peer Bullying Scale are presented in Table 1.

Table 1: Arithmetic Means and Standard Deviations of Academic Motivation Scale and Peer Bullying Scale Scores

\begin{tabular}{|l|l|l|c|c|c|c|}
\hline \multicolumn{1}{|c|}{ Scores } & $\mathrm{n}$ & Minimum & Maximum & $\overline{\mathrm{X}}$ & SD \\
\hline $\begin{array}{l}\text { Academic } \\
\text { Motivation Scale }\end{array}$ & $\begin{array}{l}\text { Extrinsic } \\
\text { Motivation }\end{array}$ & 262 & 16 & 80 & 42.73 & 10.61 \\
& $\begin{array}{l}\text { Intrinsic } \\
\text { Motivation }\end{array}$ & 262 & 17 & 85 & 54.43 & 15.65 \\
\hline $\begin{array}{l}\text { Peer Bullying } \\
\text { Scale }\end{array}$ & Bully & 262 & 0 & 172 & 18.08 & 26.49 \\
\hline
\end{tabular}

According to the results seen on Table 1, adolescents' mean score of Extrinsic Motivation Subscale of Academic Motivation Scale is $42.73 \pm 10.61$. The scores vary between 16 and 80 . The mean score of Intrinsic Motivation Subscale 54.43 \pm 15.65 and the scores vary between 17 and 85. When the scores of the Peer Bullying Scale is examined, it is seen that the mean of the Bully Subscale is $18.08 \pm 26.49$. The scores of the subscale vary between 0 and 172 . On the other hand, the mean of the Victim Subscale is 37.89 \pm 35.42 . The scores of the subscale vary between 0 and 156 .

The Spearman's correlation coefficient results of the adolescents' Academic Motivation Scale and Peer Bullying Scale are presented in Table 2.

Table 2: The Spearman's Correlation Coefficient Results of Academic Motivation Scale and Peer Bullying Scale

\begin{tabular}{|c|c|c|c|c|}
\hline Subscales & 1 & 2 & 3 & 4 \\
\hline 1. Academic Motivation-Extrinsic & - & $.240^{* *}$ & $.186^{* *}$ & .102 \\
\hline 2. Academic Motivation-Intrinsic & $.240^{* *}$ & - & $-.206^{* *}$ & $-.172^{* *}$ \\
\hline
\end{tabular}




\section{SOCIAL SCIENCES IN THE 21ST CENTURY}

\begin{tabular}{|r|c|c|c|c|}
\hline 3. Peer Bullying-Bully & $.186^{* *}$ & $-.206^{* *}$ & - & $.613^{* *}$ \\
\hline 4. Peer Bullying-Victim & .102 & $-.172^{* *}$ & $.613^{* *}$ & - \\
\hline$* p<.05, * * p<.01$ & & & & \\
\hline
\end{tabular}

As can be seen on Table 2, the Extrinsic Motivation subscale of Academic Motivation Scale is found to be significantly and positively correlated with the Bully $(r=.186, p<.01)$ subscale of Peer Bullying Scale. On the other hand, the Intrinsic Motivation subscale of Academic Motivation is found to be significantly and negatively correlated with both the Bully $(r=-.206, p<.01)$ and the Victim $(r=-.172, p<.01)$ subscales of Peer Bullying Scale.

\section{Discussion}

In the present study, it was aimed to examine the relationship between peer bullying and academic motivation in secondary school students. As a result it was found that adolescents' level of the extrinsic motivation increase and intrinsic motivation decrease as their level of bullying acts increase. On the other hand, the adolescents' level of the intrinsic motivation is found to decrease as their level of victimization in bullying acts increase. Although the correlations were weak, the above-mentioned findings were statistically significant whereas no significant association was found between being a victim of peer bullying and extrinsic motivation. It is thought that these results provide evidence related to the link between peer bullying acts and academic motivation of the secondary school students.

In the literature, most studies conducted on the subject have focused on the correlates of peer victimization by providing evidences related to influences of peer bullying at school. A meta-analytic study of Nakamoto and Schwartz (2010), in which 33 studies were reviewed, revealed that victimization by peers is linked to poor academic adjustment and mastery. In line with this finding, in this study victimization by peers is found to be negatively related to intrinsic academic motivation. According to Lepper (2005), intrinsic motivation refers to curiosity, challenge and independent mastery. Parallel to this argument, it is thought that being a victim of bullying may be causing emotional distress and negatively influencing the adolescents' engagement in academic tasks. A number of studies in the literature provided evidences in accordance with this finding of the present study. In a study Juvonen et al. (2011), examined how bullying experiences are associated with academic performances in a sample of 2300 middle school students. In the study, it was found that being a victim of bullying acts by peers at school is highly associated with poor academic disengagement. Another study, in which Tortura et al. (2014) investigated the influences of peer victimization on the academic achievement in middle school adolescents, it was found that victimization by peers was a significant predictor of low academic competence by way of poorer engagement in school tasks and psychological distress. In the study it was stressed out that bullying impacts the school environment, by complicating the learning procedure. The adolescents who are bullied may feel fearful and intimidated that they may be focusing all their attention to deal with the stressful effects of being bullied rather than the academic tasks; feel depressed and loose their curiosity due to depression they experience; invest all their efforts in avoiding being humaliated and harmed.

On the other hand, Lepper (2005) argued that extrinsic motivation refers to depending on teacher instead of individual curiosity and challenge. This component of academic motivation also includes a desire to please teacher and being stimulated by easy work. In the present 


\section{SOCIAL SCIENCES IN THE 21ST CENTURY}

study, the adolescents who had higher levels of bullying acts had higher extrinsic and lower intrinsic motivation. Smith (2011) argued that bullying children, although they may have high social intelligence, may adhere aggressive behaviors and attitudes towards other children, may display defensive and hostile motives at school. According to Kaukianen et al. (2002) these problem behaviors might be resulting from learning difficulties and/or bullying might be used as a strategy for distracting attention. On the other hand, children with low academic skills might be rejected by their peers and these children may relate to bullying (Toblin et al., 2005). Consequently, the difficulties in terms learning might be one of the reasons why intrinsic motivation is lower in adolescents who are involved in bullying acts. The bullies are also argued to be more manipulative and prone to use aggressive acts as a strategy for reaching their social goals despite of the rules and limitations (Pekel-Uludağlı ve Uçanok, 2005; Dijkstra et al., 2008). The bully adolescents might be considering the teacher as an authority figure to expose rules and control their behaviors and be more dependent on teachers as the rulers. An explanation of why bullies have higher extrinsic motivation might be that they might be more inclined to be stimulated by external forces such as rewards or appraisals; and/or the external forces might be motivating their behaviors in the lack of intrinsic motives.

The results of the present study provide findings to better understand the components of academic motivation in adolescents invloved in peer bullying, either as the bully or the victim. It is thought that the concept of peer bullying must be paid special attention when trying to understand the causes of academic disengagement and to improve learning environment in middle schools. These findings are also important as they provide recent and confirming proof that bullying as a psycho-social stressor is linked to academic motivation. In early adolescence, relationships with peers play an important role in academic motivation. Therefore educators, school mental health proffessionals and parents must pay attention to peer dynamics in their efforts to support adolesents' academic success. In efforts to improve and maintain a healthy school environment anti-bullying policies should be the priority. As the victims and the bully roles become stable during early adolescence, it is improtant that the anti-bullying interventions should commence in earlier periods, should be continious and the maintinance of these interventions should be ensured as in each developmental stage the dynamics of bullying may differ. School based interventions should include improvement of school climate as a whole to prevent bullying, provide social support systems for the students and their parents, reduce aggressive behaviors of the adolescents while providing them social skills and assertiveness training; promoting awareness about classroom rules and anti-bullying school policies.

Besides the significance of the findings, a number of limitations of the present study should be mentioned as well. The strength of the correlations were weak despite their significance. It is thought that this result might be due to the limited sample size on the contrary of the relatively high number of items administered in the forms. It would be beneficial to increase the sample size and to improve both the internal and the external validity of the research findings in the upcoming studies. Second limitation to be mentioned is that the data of the study depend on the self-report measures. Self-reports of bullying in particular might be inaccurate and less likely to reveal findings related to the subject of concern. Future studies should utilize a wider variety of data resources such as school reports, observations and interviews. It should also be pointed out that in this study the relation beween peer bullying academic motivation is examined without controlling the effects of 


\section{SOCIAL SCIENCES IN THE 21ST CENTURY}

individual factors such age, gender and socio-economic background. Future studies should particularly take the diverse social structure of the Turkish sample into account when examining peer bullying and academic motivation.

\section{References}

[1] Ayas, T., \& Pişkin, M. (2015). Akran Zorbalı̆̆ı Belirleme Ölçeği Ergen Formu. Akademik Bakış Dergisi, 50, 316-324.

[2] Bacanl1, H. \& Şahinkaya, Ö. (2011). The adaptation Study of Academic Motivation Scale into Turkish. Procedia Social and Behavioral Sciences, 12, 562-567.

[3] Bradshaw, C. P., \& Johnson, R. M. (2011). The social context of bullying and peer victimization: An introduction to the special issue. Journal of School Violence, 10(2), 107-114.

[4] Bradshaw, C. P. Waasdrop, T. E., \& Johnson, S. L. (2015). Overlapping verbal, relational, physical, and electronic forms of bullying in adolescence: Influence of school context. Journal of Clinical Child \& Adolescent Psychology, 44(3), 494-508. 


\section{SOCIAL SCIENCES IN THE 21ST CENTURY}

[5] Blood, G. W., Blood, I. M., Tramontana, G. M., Sylvia, A. J., Boyle, M. P., \& Motzko, G. R. (2011). Self-reported experience of bullying of students who stutter: Relations with life satisfaction, life orientation, and self-esteem. Perceptual and Motor Skills, 113(2), 353364.

[6] Dijkstra, J. K., Lindenberg, S. \& Veenstra, R. (2008).Beyond the class norm: Bullying behavior of popular adolescents and its relation to peer acceptance and rejection. $\mathbf{J}$ Abnorm Child Psychol, 36, 1289-1299.

[7] Deschamps, R., \& McNutt, K. (2016). Cyberbullying: What's the problem? Canadian Public Administration, 59, 45-71.

[8] Dupper, D. R. (2013). School bullying, new perspectives on a growing problem. U. K.. : Oxford University Press.

[9] Espelage, D. L. \& Holt M. K. (2001) Bullying and victimization during early adolescence. Journal of Emotional Abuse, 2(2-3), 123-142.

[10]Espelage, D. L., Hong, J. S., Rao, M. A. \& Low, S. (2013). Associations between peer victimization and academic performance, Theory Into Practice, 52, 4, 233-240.

[11] Gladden, R. M., Vivolo-Kantor, A. $\quad$ M., \& Hamburger, M.E. (2014). Bullying surveillance among youths: uniform definitions for public health and recommended data elements, Version 1.0. Atlanta, GA: National Center for Injury Prevention and Control, Centers for Disease Control and Prevention and U.S. Department of Education.

[12] Graham, S. (2016). Victims of bullying in schools. Theory Into Practice, 55(2), 136-144.

[13] Graham, S. , Bellmore, A.D. , \& Mize, J. ( 2006). Peer victimization, aggression, and their co-occurrence in middle school: Pathways to adjustment problems. Journal of Abnormal Child Psychology, 34, 363-378.

[14]Hinduja, S., \& Patchin, J. W. (2010). Bullying, cyberbullying, and suicide, Archives of Suicide Research, 14(3), 206-221.

[15]Hunter, S. C., Boyle, J. M. E., \& Warden, D. (2007). Perceptions and correlates of peervictimization and bullying. British Journal of Educational Psychology, 77, 797-810.

[16]Juvonen, J., Wang, Y., \& Espinoza, G. (2011). Bullying Experiences and Compromised Academic Performance Across Middle School Grades. The Journal of Early Adolescence, 31(1), 152-173.

[17] Kaltiala-Heino, R., Rimpela, M., Rantanen, P., \& Rimpela, A. (2000). Bullying at school - an indicator of adolescents at risk for mental disorders. Journal of Adolescence, 23, 661-674.

[18] Klomek, A. B., Marrocco, F., Kleinman, M.,Schonfeld, I. S., \& Gould, M. S. (2008). Peer victimization, depression, and suicidiality in adolescents. Suicide and Life-Threatening Behavior, 38(2), 166-180.

[19] Kaukiainen, A., Salmivalli, C., Lagerspetz, K., Tamminen, M., Vauras, M., et al. (2002). Learning difficulties, social intelligence and self-concept: Connections to bullyvictim problems. Scandinavian Journal of Psychology. 43(3), 269-278.

[20]Kulasızoğlu, A. (2005). Psychology of adolescence. İstanbul: Remzi Publishing. 


\section{SOCIAL SCIENCES IN THE 21ST CENTURY}

[21] Konishi, C., Hymel, S.,Zumbo, B. D., \& Li, Z. (2010). Do school bullying and studentteacher relationships matter for academic achievement? A multilevel analysis. Canadian Journal of School Psychology, 25(1) 19-39.

[22]Langos, C., \& Sarre, R. (2015). Responding to cyberbullying: The case for family conferencing. Deakin Law Review, 20, 299-319.

[23]Lepper, M. R., Corpus, J. H., \& Iyengar, S. S. (2005). Intrinsic and extrinsic motivational orientations in the classroom: Age differences and academic correlates. Journal of Educational Psychology, 97, 184-196.

[24] Mitchell, B. L. (2018). The state of bullying in schools. In J. U'Mofe (Ed.), Bullying prevention and intervention at school integrating theory and research into best practices (pp.1-16). Switzerland: Springer Nature.

[25] Nakamoto, J., \& Schwartz, D. (2010). Is peer victimization associated with academic achievement? A meta-analytic review. Social Development, 19, 2, 221-242.

[26] Nansel, R., Craig, W., Overpeck, M. D., Saluja, G., \& Ruan, J. (2004). Health behavior in school aged children, b. cross-national consistency in the relationship between bullying behaviors and psychosocial adjustment. Arch. Pediatr. Adolesc. Med., 158, 730-736.

[27] Olweus, D. (2013). School bullying: Development and some 1mportant challenges. Annual Review of Clinical Psychology, 9, 751-780.

[28]Peeters, M., Cillessen, A. H., \& Scholte, R. H. J. (2010). Clueless or powerful? Identifying subtypes of bullies in adolescence. Journal of Youth and Adolescence, 39(9), 1041-1052.

[29]Pekel-Uludağlı, N., \& Uçanok, Z. (2005). Akran zorbalığg gruplarında yalnızlık ve akademik başarı ile sosyometrik statüye göre zorba/kurban davranış türleri. Türk Psikoloji Dergisi, 20(56), 77-92.

[30] Rosen, L. H., Scott, S. R., \& DeOrnellas, K. (2017). An overview of school bullying. In Rosen, L. H., DeOrnellas, K., Scott, S. R. (Eds.), Bullying in school, perspectives from school staff, students, and parents (pp. 1-22), U. S. A.: Palgrave Macmillan.

[31] Schott, R. M. (2014). The social concept of bullying: philosophical reflections on definitions. In R. M. Schott, D. M. Søndergaard (Eds.), School bullying, new theories in context (pp. 21-46), New York: Cambridge University Press.

[32] Seeds, P. M., Harkness, K. L., \& Quilty, L. C. (2010) Parental maltreatment, bullying, and adolescent depression: Evidence for the mediating role of perceived social support, Journal of Clinical Child \& Adolescent Psychology, 39(5), 681-692.

[33] Stapinski, L. A., Bowes, L., Wolke, D., Pearson, R., Mahedy, L., Button, K. S., Lewis, G., \& Araya, R. (2014). Peer victimization during adolescence and risk for anxiety disorders in adulthood: A prospective cohort study. Depression and Anxiety, 31, 574582.

[34] Smith, P. K. (2011). Bullying in schools: the research background. In R. Dixon (Ed.), Rethinking school bullying (pp. 22-37), New York: Cambridge University Press, 


\section{SOCIAL SCIENCES IN THE 21ST CENTURY}

[35] Schwartz, D., Gorman, A.H., Nakamoto, J., \& Toblin, R.L. ( 2005). Victimization in the peer group and children's academic functioning. Journal of Educational Psychology, 97, 425-435.

[36] Slee, P. T., \& Skrzypiec, G. (2016). Well-being, positive peer relations and bullying in school settings, positive education. Switzerland: Springer International Publishing.

[37] Tabachnick, B. G., \& Fidel, L. S. (2013). Using multivariate statistics. New York: Pearson.

[38] Toblin, R. L., Schwartz, D., Gorman, A. H., \& Abou-Ezzeddine, T. (2005). Socialcognitive and behavioral attributes of aggressive victims of bullying. Journal of Applied Developmental Psychology, 26(3), 329-346.

[39]Tortura, C. M. W., Karver, M. S., \& Gesten, E. L. (2014). Psychological distress and student engagement as mediators of the relationship between peer victimization and achievement in middle school youth. $J$ Youth Adolescence, 43, 40-52.

[40] UNESCO (2017). School violence and bullying: Global status report. Paris: United Nations Educational Scientific and Cultural Organization.

[41] Vaillancourt, T., McDougall, P., Hymel, S., Krygsman, A., Miller, J., Stiver, K., \& Davis, C. (2008). Bullying: Are researchers and children/youth talking about the same thing? International Journal of Behavioral Development, 32(6), 486-495. 